\title{
NOTE
}

\section{Variations in the stable carbon isotope ratios of Zelkova serrata leaves from roadside trees in Toyama City, Japan}

\author{
YASUHIRO KIYOSU and Mitsu KIDOGUCHI \\ Department of Environmental Biology and Chemistry, Toyama University, Toyama 930-8555, Japan
}

(Received October 27, 1999; Accepted April 26, 2000)

\begin{abstract}
Nitrogen contents and stable carbon isotope ratios of Zelkova serrata leaves collected from roadside trees in Toyama City, Japan were measured in order to judge the stress due to water availability and nutrient efficiency. Furthermore, the source of urban atmospheric $\mathrm{CO}_{2}$ was examined from the isotopic discrimination between Zelkova serrata leaves and $\mathrm{CO}_{2}$ in the ambient air based on the correlation between carbon isotope ratio and content of $\mathrm{CO}_{2}$, since there was no stress associated with the roadside trees. The carbon isotope ratio of roadside tree leaves decreases with increasing traffic. This suggests that the atmospheric $\mathrm{CO}_{2}$ in urban street is contaminated by exhaust gases of car.
\end{abstract}

\section{INTRODUCTION}

When plants fix atmospheric $\mathrm{CO}_{2}$ by photosynthesis, carbon isotope fractionation associated with carboxylation and diffusion occurs. Therefore, plants are enriched in ${ }^{12} \mathrm{C}$ relative to the atmosphere. The isotopic discrimination between $\mathrm{C}_{3}$ plants and atmospheric $\mathrm{CO}_{2}$ is shown in the following equation (Farquhar et al., 1989):

$$
\delta^{13} \mathrm{C}_{\mathrm{p}}=\delta^{13} \mathrm{C}_{\mathrm{a}}-\left(4.4+22.6 \times \mathrm{C}_{\mathrm{i}} / \mathrm{C}_{\mathrm{a}}\right)
$$

where $\delta^{13} \mathrm{C}_{\mathrm{p}}$ is the carbon isotope ratio of plants, $\delta^{13} \mathrm{C}_{\mathrm{a}}$ the carbon isotope ratio of atmospheric $\mathrm{CO}_{2}$, $\mathrm{C}_{\mathrm{i}}$ the internal gas-phase content of $\mathrm{CO}_{2}$ and $\mathrm{C}_{\mathrm{a}}$ the external $\mathrm{CO}_{2}$ content. When isotope discrimination between plants and atmospheric $\mathrm{CO}_{2}$ is established, the leaf carbon isotope ratio depends on that of the $\mathrm{CO}_{2}$ in the ambient air.

The $C_{i} / C_{a}$ ratios of plants, however, change according to the long-term water stress and/or nutrient conditions (e.g., Toft et al., 1989; Read et al., 1992). For example, the ratios vary from 0.64 to 0.40 for Zelkova serrata due to soil water content (Takahashi, 1995). Consequently, leaves exhibit more positive $\delta^{13} \mathrm{C}$ values under water stressed conditions, values changing by a much as $5.4 \%$. On the other hand, if there is no stress on urban roadside trees, the $\delta^{13} \mathrm{C}$ values of leaves are mainly controlled by those of atmospheric $\mathrm{CO}_{2}$.

The aim of present study is to judge the stress due to water availability and nutrient efficiency from investigation of Zelkova serrata carbon isotope and nitrogen content at Sakuradori Street in Toyama City. We also would like to clarify the source of atmospheric $\mathrm{CO}_{2}$ from the isotopic discrimination between this plant and $\mathrm{CO}_{2}$ when there is no stress associated with Zelkova serrata.

\section{EXPERIMENTAL}

\section{Sampling}

Zelkova serrata leaves at height of $4 \mathrm{~m}$ from Sakuradori roadside trees were collected in $6 \mathrm{Sep}$ tember 1996 and the ambient air from street crossings in Toyama City, monthly during May-November in 1996-1997. The air was sampled in a Aluminized Polyethylene bag by a two way gastight syringe. The traffic at street crossings was 
averaged from the data of May-September in 1996.

\section{Analytical method}

Leaf samples were dried thoroughly for $6 \mathrm{hr}$ at $80^{\circ} \mathrm{C}$ prior to combustion and ground to a powder. After $4 \mathrm{mg}$ of leaf samples has been weighed into a cut quartz tube, the sample was mixed with $0.5 \mathrm{~g}$ of $\mathrm{CuO}$ by gentle shaking. Approximately $0.25 \mathrm{~g}$ of reduced copper was added to the combustion tube on top of the sample/CuO mixture. When a vacuum was achieved, the combustion tubes were sealed with a gas/oxygen torch. The muffle furnace in which each sealed tube was placed was heated to $900^{\circ} \mathrm{C}$ and the temperature maintained for $2 \mathrm{hr}$. The gases produced by combustion of leaf sample revealed the presence of only $\mathrm{CO}_{2}, \mathrm{H}_{2} \mathrm{O}$ and $\mathrm{N}_{2}$. After the $\mathrm{CO}_{2}$ and $\mathrm{N}_{2}$ in leaf sample were separated with Porapak Q by helium carrier and their contents were determined by a TCD gas chromatograph, then the remaining $\mathrm{CO}_{2}$ was separated from the other gases by cryogenic distillation (Kidoguchi, 1996). The $\mathrm{CO}_{2}$ produced was manometrically measured.

The concentrations of atmospheric $\mathrm{CO}_{2}$ were measured by a FID gas chromatograph equipped with methanizer. For the measurement of carbon isotope ratios, atmospheric $\mathrm{CO}_{2}$ is condensed out in a trap cooled by liquid nitrogen (Craig, 1953). However, minor amount of atmospheric $\mathrm{N}_{2} \mathrm{O}$, which has the same molecular masses as $\mathrm{CO}_{2}$ but has quite different abundances of isotope species, is also trapped with $\mathrm{CO}_{2}$ because both molecules have almost the same physical properties. In the present study, we reduced $\mathrm{N}_{2} \mathrm{O}$ to $\mathrm{N}_{2}$ through $\mathrm{CO}_{2}$ $\mathrm{N}_{2} \mathrm{O}$ mixture over copper heated at $500^{\circ} \mathrm{C}$ and pumped away the $\mathrm{N}_{2}$ (Kidoguchi, 1998).

The $\mathrm{CO}_{2}$ thus purified was analyzed for its $\delta^{13} \mathrm{C}$ with the Micromass PRISM mass spectrometer. The overall reproducibility for both the leaf and air samples was $\pm 0.1 \%$.

\section{RESULTS AND DISCUSSION}

Carbon isotope ratios and nitrogen contents of Zelkova serrata leaves range from -32.4 to
$-29.7 \%$ and from 1.6 to $2.1 \mathrm{wt} \%$, respectively (Table 1). On the contrary, $\delta^{13} \mathrm{C}$ values and contents of atmospheric $\mathrm{CO}_{2}$ during May-November, 1996-1997 at street crossings in Sakuradori Street are -11.2 to $-9.2 \%$ and 402 to $440 \mathrm{ppm}$, respectively (Fig. 1). The carbon isotope ratio of $\mathrm{CO}_{2}$ decreases with increasing $\mathrm{CO}_{2}$ content of air as shown in Fig. 1. No seasonal variations in $\delta^{13} \mathrm{C}$ values of tree leaves and atmospheric $\mathrm{CO}_{2}$ at street crossings along Sakuradori Street were clearly observed (Kidoguchi, 1998).

\section{Isotope discrimination}

In order to judge the stress, substituting the averaged $\delta^{13} \mathrm{C}$ value $\left(-10.1 \%\right.$ ) of atmospheric $\mathrm{CO}_{2}$ along Sakuradori Street and the $\mathrm{C}_{\mathrm{i}} / \mathrm{C}_{\mathrm{a}}$ ratios from 0.64 and 0.40 into Eq. (1) the carbon isotope ratios of Zelkova serrata ranging from -29.0 to $-23.5 \%$ are obtained. Since the tree leaves are depleted in $\delta^{13} \mathrm{C}$ relative to the calculated values by amounts up to about 5\%o, there are no stress associated with the roadside trees. In this case, the $\delta^{13} \mathrm{C}$ values of Zelkova serrata leaf should have been constant, but the values are scattered actually. At

Table 1. Carbon isotope ratio, and the carbon and nitrogen contents of Zelkova serrata leaves (sampled on September 6, 1996) from sixteen trees along Sakuradori Street in Toyama City

\begin{tabular}{cccc}
\hline Sample No. & $\begin{array}{c}\text { Carbon } \\
\text { (wt. \%) }\end{array}$ & $\begin{array}{c}\text { Nitrogen } \\
\text { (wt. \%) }\end{array}$ & $\begin{array}{c}\delta^{13} \mathrm{C} \\
(\% \text { ) }\end{array}$ \\
\hline ZS-01 & 46 & 2.1 & -31.6 \\
ZS-02 & 47 & 1.8 & -32.4 \\
ZS-03 & 45 & 1.7 & -31.4 \\
ZS-04 & 44 & 2.1 & -31.7 \\
ZS-05 & 47 & 1.8 & -32.0 \\
ZS-06 & 47 & 1.9 & -32.0 \\
ZS-07 & 47 & 2.1 & -30.1 \\
ZS-08 & 47 & 2.1 & -32.2 \\
ZS-09 & 42 & 1.6 & -29.7 \\
ZS-10 & 47 & 1.9 & -31.2 \\
ZS-11 & 49 & 1.8 & -30.0 \\
ZS-12 & 41 & 2.1 & -30.5 \\
ZS-14 & 47 & 2.1 & -30.8 \\
ZS-15 & 43 & 1.8 & -32.4 \\
ZS-16 & 46 & 1.8 & -30.8 \\
\hline
\end{tabular}

ZS-01, ZS-08, ZS-12, ZS-15, ZS-16: Street crossings. 
the sampling point of present study, there are no differences in meteorological conditions, such as relative humidity and light intensity that would have caused the change in the isotope ratio (e.g., Madhavan et al., 1991). Therefore, variations in $\delta^{13} \mathrm{C}$ values of Zelkova serrata depend on those of the $\mathrm{CO}_{2}$ in the air and reflect the fractionation in the atmospheric $\mathrm{CO}_{2}$.

From the Zelkova serrata leaf nitrogen content, it was expected that all of these trees were nutritionally deficient, judging from the values reported by Takahashi (1995). Since the stress due to nutrition deficiency, however, did not affect the leaf $\delta^{13} \mathrm{C}$ values, it was not responsible for the variation in isotope ratios (Kidoguchi, 1996).
Therefore, the variations depend on source of atmospheric $\mathrm{CO}_{2}$.

\section{Source of $\mathrm{CO}_{2}$ in urban street}

As shown in Fig. 2, the $\mathrm{CO}_{2}$ content at some street crossings increases with increasing the traffic in Toyama City. Furthermore, the $\delta^{13} \mathrm{C}$ value of atmospheric $\mathrm{CO}_{2}$ become more negative with increasing $\mathrm{CO}_{2}$ content in the ambient air. On the contrary, the roadside tree leaves exhibit more negative $\delta^{13} \mathrm{C}$ values with increasing the traffic (Fig. 3). This suggests that most of the atmospheric $\mathrm{CO}_{2}$ in urban street is mainly derived from exhaust gases of cars. Consequently, the atmospheric $\mathrm{CO}_{2}$ content can be estimated by measuring leaf

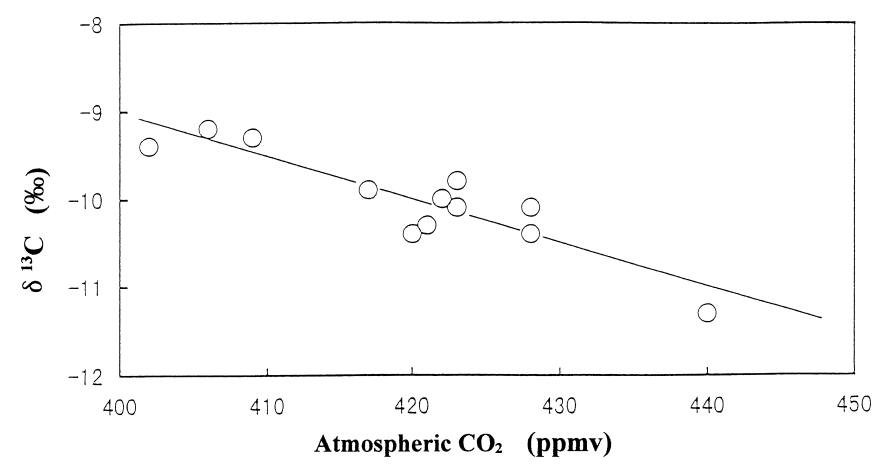

Fig. 1. Plot of $\delta^{13} \mathrm{C}$ values versus content of $\mathrm{CO}_{2}$ from air samples during May-November, 1996-1997, at Sakuradori Street in Toyama City. The line is drawn by the least-squares method.

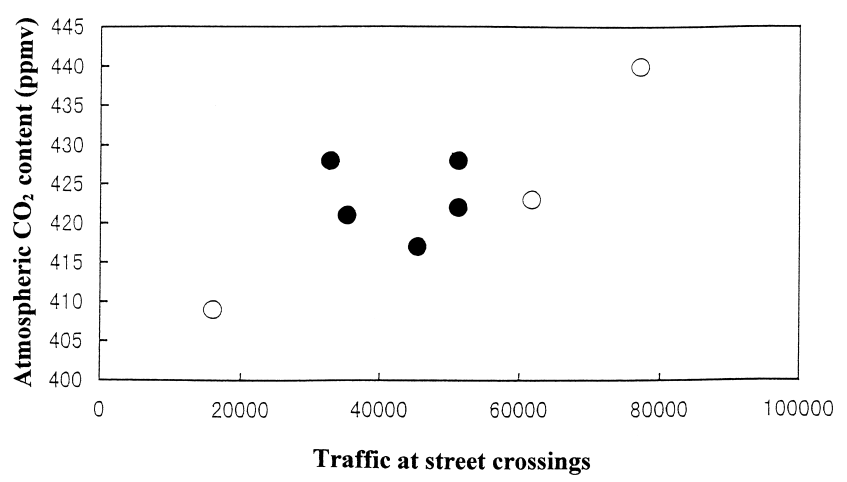

Fig. 2. Relationship between atmospheric $\mathrm{CO}_{2}$ contents vs. traffic at street crossings in Toyama City. The air was sampled on September 6, 1996, and the traffic (car numbers per day) is the average value for the data of MaySeptember in 1996. Closed circles are from Sakuradori Street (at the crossings corresponding to the tree positions of ZS-01, ZS-08, ZS-15, ZS-16 in Table 1) and open circles from other streets. 


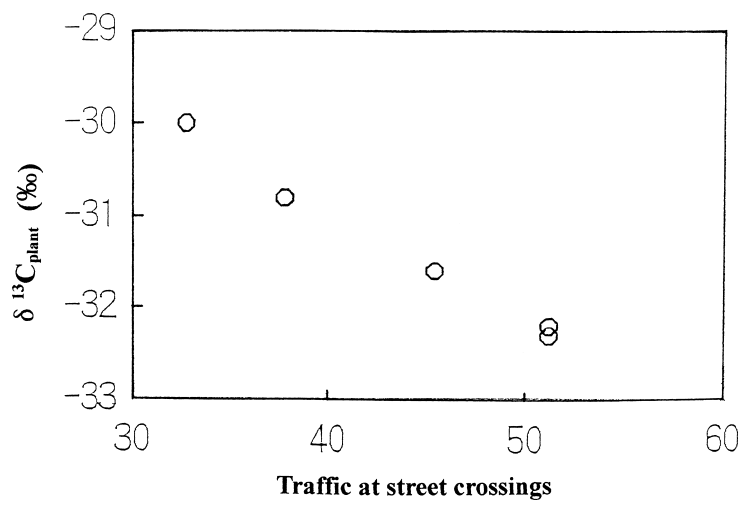

Fig. 3. Carbon isotope ratios in Zelkova serrata leaves (sampled on September 6, 1996, ZS-01, ZS-08, ZS-12, ZS-15, ZS-16 in Table 1) vs. traffic (May-September, 1996) at street crossings in Sakuradori Street. The traffic indicates car numbers $(\times \sim 1000)$ per day.

$\delta^{13} \mathrm{C}$ values, if the traffic along each street is presumed. Assuming that in the roadside tree there is no stress such as water deficiency, the behavior of urban atmospheric $\mathrm{CO}_{2}$ can be clarified from the examination of the leaf $\delta^{13} \mathrm{C}$ values for all city roadside trees.

Acknowledgments-The author wishes to thank $\mathrm{H}$. Satake for his technical assistance. We also thank J. Matsuda, H. Wada and anonymous reviewer for their suggestions to improve this manuscript.

\section{REFERENCES}

Craig, H. (1953) The geochemistry of the stable carbon isotopes. Geochim. Cosmochim. Acta 3, 53-92.

Farquhar, G. D., Ehleringer, J. R. and Hubick, K. T. (1989) Carbon isotope discrimination and photosynthesis. Annu. Rev. Plant Physiol. Plant Mol. Biol. 40, 503-537.

Kidoguchi, M. (1996) Carbon isotope ratio of street trees and atmospheric environment in Toyama City. Unpub. Bachelor's Thesis, Toyama Univ. (in Japanese).

Kidoguchi, M. (1998) Carbon isotope ratio of street trees as indicater of urban mospheric environment. Unpub. Master's Thesis, Toyama Univ. (in Japanese).

Madhavan, S., Treichel, I. and O'Leary, M. H. (1991) Effects of relative humidity on carbon isotope fractionation in plants. Botanica Acta 104, 292-294.

Read, J. J., Johnson, D. A., Assay, K. H. and Tieszen, L. (1992) Carbon isotope discrimination: relationship to yield, gas exchange, and water-use efficiency in field-grown crested wheat grass. Crop Science 32, 168-175.

Takahashi, K. (1995) Carbon isotope ratio and the nitrogen content of leaves: A possible indicator of limiting factor for tree growth. Chikyukagaku 29, 127 136 (in Japanese).

Toft, N. L., Anderson, J. E. and Nowak, R. S. (1989) Water use efficiency and carbon isotope composition of plants in a cold desert environment. Oecologia 80, $11-18$. 